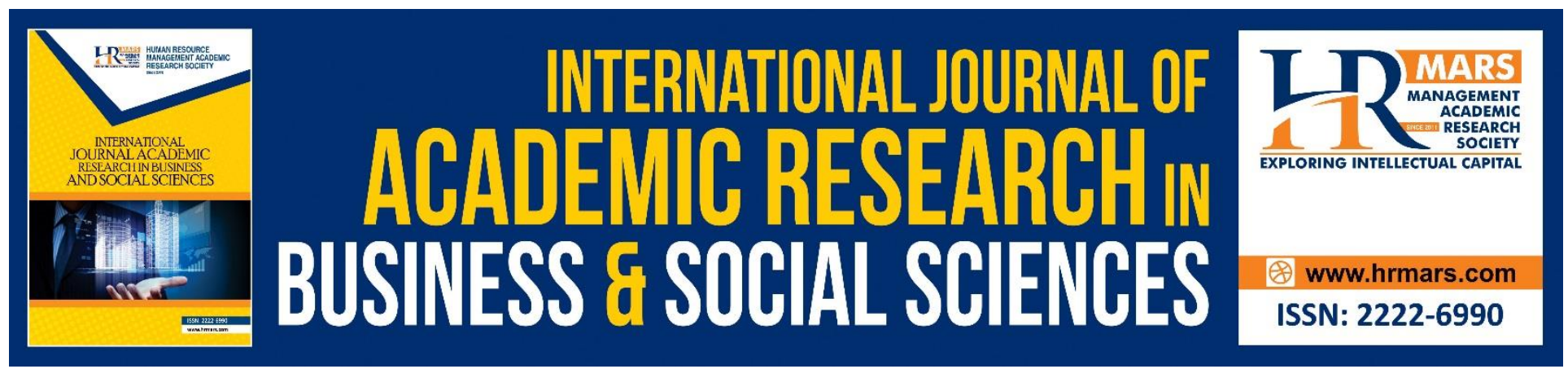

\title{
The Effects of Gender Diversity in The Boardroom on Firm Performance among top 50 Listed Companies in Malaysia
}

\author{
Ahmad Syakir Mustaqim Ahmad Sabri, Ahmad Syubaili Mohamed, Salawati \\ Sahari
}

To Link this Article: http://dx.doi.org/10.6007/IJARBSS/v10-i8/7672

DOI:10.6007/IJARBSS/v10-i8/7672

Received: 08 May 2020, Revised: 04 June 2020, Accepted: 20 July 2020

Published Online: 16 August 2020

In-Text Citation: (Sabri, Mohamed, \& Sahari, 2020)

To Cite this Article: Sabri, A. S. M. A., Mohamed, A. S., \& Sahari, S. (2020). The Effects of Gender Diversity in The Boardroom on Firm Performance among top 50 Listed Companies in Malaysia. International Journal of Academic Research in Business and Social Sciences. 10(8), 1044-1054.

Copyright: @ 2020 The Author(s)

Published by Human Resource Management Academic Research Society (www.hrmars.com)

This article is published under the Creative Commons Attribution (CC BY 4.0) license. Anyone may reproduce, distribute, translate and create derivative works of this article (for both commercial and non-commercial purposes), subject to full attribution to the original publication and authors. The full terms of this license may be seen

at: http://creativecommons.org/licences/by/4.0/legalcode

Vol. 10, No. 8, 2020, Pg. 1044 - 1054

http://hrmars.com/index.php/pages/detail/IJARBSS

JOURNAL HOMEPAGE

Full Terms \& Conditions of access and use can be found at http://hrmars.com/index.php/pages/detail/publication-ethics 


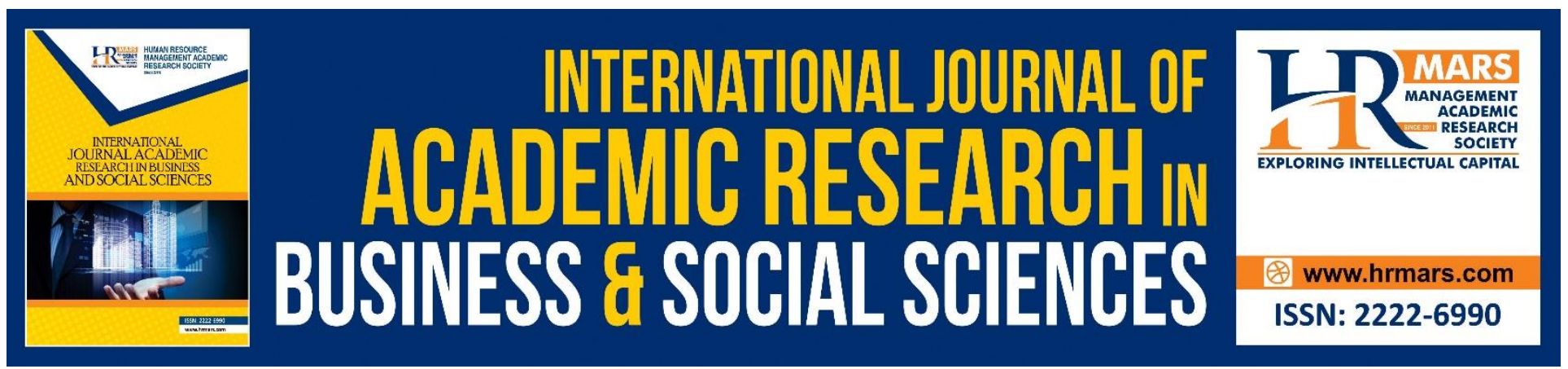

\title{
The Effects of Gender Diversity in The Boardroom on Firm Performance among top 50 Listed Companies in Malaysia
}

\section{Ahmad Syakir Mustaqim Ahmad Sabri, Ahmad Syubaili Mohamed, Salawati Sahari}

Faculty of Economics and Business. Universiti Malaysia Sarawak

Email: masyubaili@unimas.my

\begin{abstract}
Gender diversity is an important factor in boards because it can contribute to the functioning of boards which could potentially positively influence corporate performance. This paper aims to examine the effect of gender diversity of board members on corporate outcomes to provide guidance to top level managements for increase proportion of women in the boards. This research performs on the sample of top 50 listed corporations in Malaysia from the year 2014 to 2018. Corporate performance is measured using return on assets while percentage of female directors represents gender diversity. The results from OLS regression model reveal that gender diversity is positively related to corporate performance. From these findings, the higher proportion of females in boards can have a substantial impact on the performance of the corporation.
\end{abstract}

Keywords: Gender Diversity, Corporate Performance, Return on Assets.

Introduction

Financial performance is a general measure of a company's overall financial health over a given period. It is also known as profitability and can be measure using several methods but, the most used is financial analysis where profitability ratio is applied. The profitability ratio will show how well a company utilizes its assets to produce profit and value to shareholders. There are several studies conducted that examined various variables that may impact corporate performance such as company size, company age and board size, however, the emerging one in this era is gender diversity of board director. In today's business world, gender diversity has quickly become an alarming concern. Malaysia seems to be lagging in encouraging women's involvement in top level management in the Malaysian Public Listed Companies (PLCS), especially before 2015. From 2011 to 2013, the percentage of women representatives holding the role of board members is 8.6 percent, 10 percent, and 10.6 percent respectively, in which they are still at low rates of below 15 percent. Nevertheless, this percentage rose slightly to 14.3 percent in 2014 . The lack of involvement of females in top level management was steadily improved in 2011, when Malaysia imposed a requirement on big 
INTERNATIONAL JOURNAL OF ACADEMIC RESEARCH IN BUSINESS AND SOCIAL SCIENCES Vol. 10, No. 8, 2020, E-ISSN: 2222-6990 @ 2020 HRMARS

companies to achieve 30 percent board diversity by 2016. The Malaysian Corporate Governance Code also demands that all businesses to report their strategy, goals, and outcomes on diversity. Study by Korn Ferry and the National University of Singapore Business School's Centre for Governance, Institutions and Organisations reported that Malaysia was the only nation in the ASEAN region to have adopted the goal and given constructive assistance to businesses to meet the objective, even as it fell short of its aim of 30 percent inclusion of women at the decision-making level before 2016. Therefore, this research is carried out to investigate the relationship of gender diversity and firm performance of top 50 listed corporations in Malaysia and address the gaps as compared to prior research.

\section{Literature Review}

Gender diversity may be defined as the mechanism by which a man and woman will benefit the company from different characteristics and abilities. Dutta and Bose 2 (2006) stated that gender diversity of management board is concerned with the female being on boards which is a vital part of board diversity. Nowadays, gender diversity is an important factor in boards because it can contribute to the functioning of boards which could potentially positively influence corporate performance. Carter et al. (2003) proposed that sex diversity may upsurge the autonomy of the board as women are most likely to pose questions, which male directors might not query. Nevertheless, there is an argument that gender diversity could reduce corporate performance due to the disputes of different views.

Some research was carried out to provide insight into gender diversity of board members and its connection to corporate performance. Nonetheless, the findings reported may be seen to be varied. The previous research by Carter, Simskins and Simpson (2007) have mentioned that sex diversity has beneficial impacts on performance mainly over audit role as well as company financial results. Erhardt, Werbel and Shrader (2003) found that the diversity of managing board was positively connected to both ROA and ROI. Moreover, Catalyst (2008) reported that on average, Fortune 500 corporations with more woman board members have performed significantly better measurements of financial performance than those with 53\% more equity earnings, $42 \%$ more revenues and $66 \%$ more returns on invested capital. Furthermore, Laffarga et al. (2015) found that sex diversity in application of the percentage of woman board members is positively associated with higher economic results, which indicated a positive impact on organizational values and results of 125 nonfinancial Spanish corporations. This study is supported by research done by Sánchez (2017), which showed that percentage of women directors to be a beneficial and significant variable in correlation to ROA or Tobin's Q, which indicated that female directors can positively influence firm performance. On the other hand, Wang, and Clift (2009) have argued the gender diversity of directors and financial performance are not strongly related and assumed it is because of very limited women directors in the sample. Rose (2007) found no any significant relation between company results and percentage of female board members and argued that directors who have unorthodox background implicitly followed the ideas of the majority of members of the traditional boards, which implies that there is little real impact on results. Besides, Darmadi (2010) also found women's representation in top level management is negatively linked to both ROA and Tobin's $Q$, indicating that women being on boards is not connected with increased level of performance. Research carried out in Malaysia by Maran and Indraah (2009), had examined the impact of board size, corporate size, and corporate age on return on assets (ROA) and return on equity (ROE) but found an insignificant impact. Even, the finding on 
INTERNATIONAL JOURNAL OF ACADEMIC RESEARCH IN BUSINESS AND SOCIAL SCIENCES Vol. 10, No. 8, 2020, E-ISSN: 2222-6990 @ 2020 HRMARS

regression using cross-sectional data is also contradictory to show the significance of diversity between board of directors with regards to corporate performance. In contrast, this finding is challenged by another research done in Malaysia by Julizaerma and Sori (2012), which discovered that a positive association exists between gender diversity and firm performance. This shows the benefit of having gender diversity in Malaysian boards but there is a possibility that the finding might different if the research covers a longer period. Thus, these empirical findings give opportunity to better comprehend the issue, in which to scrutinize the relationship between sex diversity of management board and financial results of Malaysian corporations by using ROA as the indicator. This research is carried out to scrutinize the relationship between sex diversity of managing board and corporation's financial results. Females appeared to have beneficial and significant impact on company results because of many aspects. Study done by Terjesen et al. (2009) stated that female board members are role models who inspire others as they claimed that the number of women top executives can have a beneficial influence on females' profession growth in lower positions, as it includes drawing up high-performance applicants from places other than usual and decreases the impact of old men's system. A research by Adams and Ferreira's (2009) found that not only woman board members have better attendance records than males, but eventually the more gender-diverse the boards will improve males' attendance. This proves that females positively affect male's behaviour and greater efforts to monitoring are likely to be examined in gender-diverse board members. The representation of females on board could be fully exploited if more than one female is in the boardroom, which was discussed in the literature section. This could eventually lead to the efficiency of the board resulting in a company's high performance.

The performance indicator applied in this investigation is Return on Assets (ROA), an accountingbased financial results indicator. ROA is commonly applied as financial measurement and, it is assumed to has positive association with sex diversity of board members according to the report of Adams and Ferreira (2009); Jackling and Johl (2009); Julizaerma and Sori (2012); Sánchez (2017). However, there are still several research that found negative or no association between sex diversity and company results (Rose, 2007, Maran and Indraah, 2009 and Darmadi, 2010). Different methodologies, small sample size, short observations, various controlled variables, and the lack of examination of whether board diversity is endogenous to performance might be the cause of inconsistent findings (Wang and Clift, 2009). Two research conducted in Malaysia by Maran and Indraah (2009); Julizaerma and Sori (2012) showed a contradictory result. Hence, another research that investigates ROA as performance indicator might be helpful to further explain these inconsistent results.

\section{Methodology}

This study is implying quantitative research where the finding by analysis of secondary sources is used. Based on the main objective the research that aims to scrutinize the association of gender diversity and company performance, it will focus on top 50 listed corporations in Main Market of Malaysian Bourse over the period 2014 until 2018. The data set is a panel data of moderate size within these 5 years, consisting of top 50 firms without any missing data. Due to this reason, this research will be able to collect 250 observations. Then, content analysis is conducted based on the data obtained from the annual report of the firms on Malaysian Bourse. Like most prior studies, this study will also exclude information from financial and banking institutions. This is mainly because the 
INTERNATIONAL JOURNAL OF ACADEMIC RESEARCH IN BUSINESS AND SOCIAL SCIENCES Vol. 10, No. 8, 2020, E-ISSN: 2222-6990 @ 2020 HRMARS

terms of ownership and the fiscal policies are more closely monitored and partially due to the various accounting methodologies used in the financial statement.

The data of the investigation is obtained from the firms' official webpage from Bursa Malaysia Securities Berhad as well as DataStream in Universiti Malaysia Sarawak for the published annual report for top 50 companies from the year 2014 to 2018. In addition, database from Companies Commission of Malaysia is accessed to verify the incorporation date of corporations. Detailed information about each firm is included in the data set. The components that are important are balance sheets, income statements, depreciation, total assets, revenues, and market valuation.

\section{Modelling the Variables}

The research is carried out for the cause of empirical analysis and classified according to the purpose (Robson, 2002). This study uses descriptive tests to clarify the connections between variables and to explore them. In an explanatory analysis specific data is clarified and considered (Gray, 2009). Therefore, the measurement of variables for this study can be divided into three part such as dependent, independent and control variables which are similar variables used in prior studies. In previous studies, these variables were tested and assumed to be consistent when performing the test because they can influence ROA. The measurement on each variable used is as follows:

Table-1. Measurement of Variables

\begin{tabular}{lll}
\hline \multicolumn{1}{c}{ Variables } & \multicolumn{1}{c}{ Types of Variables } & \multicolumn{1}{c}{ Measurement Indicator } \\
\hline $\begin{array}{l}\text { Percentage of } \\
\text { Female Directors }\end{array}$ & $\begin{array}{l}\text { Independent } \\
\text { variable }\end{array}$ & $\begin{array}{l}\text { Number of women directors / Number of } \\
\text { board members }\end{array}$ \\
\hline $\begin{array}{l}\text { Return on Asset } \\
\text { (ROA) }\end{array}$ & $\begin{array}{l}\text { Dependent variable } \\
\text { Number of Board }\end{array}$ & $\begin{array}{l}\text { Net Income / Total Asset } \\
\text { Meeting }\end{array}$ \\
\hline Board size & Control variable & $\begin{array}{l}\text { Total number of board meeting held during } \\
\text { the financial period }\end{array}$ \\
\hline Firm size & Control variable & Number of board members \\
\hline Firm age & Control variable & Number of years of business operation \\
\hline
\end{tabular}

For this research, the OLS-regression is constructed for the variables tested. The method ensures the multicollinearity problem is worked out first so that the fundamental regression analysis premises are fulfilled. If the residuals have constant variance, OLS estimator has minimum variance of all unbiased estimators. Furthermore, if the errors are normally distributed, hypothesis testing using $\mathrm{F}$ tests will be carried out. Hence, in this research all the regression findings are indicated using $\mathrm{f}$-statistics and the association is determined using coefficients. The relationship between sex diversity of board members and corporate performance was tested by the following regression model:

$$
R O A=60+61 \text { PWOMEN + } 62 \text { BSIZE + B3FSIZE + 64FAGE + 65BMEETING + } \varepsilon i
$$

Where:

$R O A=$ Return on Asset

$P W O M E N=$ Percentage of Women Directors

$B S I Z E=$ Board Size

$F S I Z E=$ Firm Size 
INTERNATIONAL JOURNAL OF ACADEMIC RESEARCH IN BUSINESS AND SOCIAL SCIENCES

Vol. 10, No. 8, 2020, E-ISSN: 2222-6990 @ 2020 HRMARS

FAGE $=$ Firm Age

$B M E E T I N G=$ Number of Board Meeting

$\varepsilon=$ Error term

\section{Hypothesis Development}

To examine the relationship of gender diversity and firm performance of top 50 listed companies in Malaysia, hypothesis is required. Accordance with the objectives of this research, the hypothesis used to be formed:

HO: There is a significant relationship between percentage of women directors and firm performance (ROA).

$H_{1}$ : There is a significant relationship between firm size and firm performance (ROA).

$\mathrm{H}_{2}$ : There is a significant relationship between board size and firm performance (ROA).

$H_{3}$ : There is a significant relationship between firm age and firm performance (ROA).

$H_{4}$ : There is a significant relationship between number of board meetings and firm performance (ROA).

\section{Findings}

\section{Descriptive Analysis}

In general, overall distributions are comparable to earlier research. For example, the mean of females' percentage in board is slightly higher than in the research by Maran and Indraah (2009) where they gained a mean of 13.5 percent using a sample of top 100 corporations in period 2000 until 2006 as compared to 17.1 percent in this research. This average percentage is also higher compared to the calculated percentage of females' director in boards of Malaysian corporations in 2014 and 2015 which are 14.3 percent and 15.8 percent respectively. Besides, the mean of the total number of board members at 9.10 percent is lower than in the research conducted by Laffarga et. al. (2015) which they only managed to achieve board size of 11.25 members. Next, the mean of firm size in this research measured by the natural logarithm of total assets of company is 16.08 , in which constitute the average size of corporations in the sample. Moreover, these corporations have an average of 27.50 years of operating the business in their respective sector.

Table-2. Descriptive Statistics of Variables used in the Study

\begin{tabular}{lllll}
\hline \multicolumn{1}{c}{ Variables } & $\begin{array}{l}\text { Standard } \\
\text { Deviation }\end{array}$ & Minimum & Maximum & Mean \\
& 7.673328 & -8.220000 & 42.01000 & 8.355720 \\
\hline Return on Assets & 11.23562 & 0.000000 & 57.14000 & 17.14220 \\
\hline Percentage of Females Directors & 2.154006 & 4.000000 & 15.00000 & 9.104000 \\
\hline Total No. of Board of Members & 1.608696 & 10.00000 & 19.00000 & 16.07960 \\
\hline Natural logarithm of total assets & 16.11237 & 1.000000 & 58.00000 & 27.50000 \\
\hline No. of Years of Business Operation & 3.794530 & 3.000000 & 25.00000 & 7.056000 \\
\hline $\begin{array}{l}\text { Number of Board Meeting held in a } \\
\text { year }\end{array}$ & & & & \\
\hline
\end{tabular}

\section{Correlation Analysis}

Table 3 shows the correlation between each variable tested in this research and the controlled variables when it is analysed using bivariate analysis. Generally, some of the variables are highly 
INTERNATIONAL JOURNAL OF ACADEMIC RESEARCH IN BUSINESS AND SOCIAL SCIENCES Vol. 10, No. 8, 2020, E-ISSN: 2222-6990 @ 2020 HRMARS

correlated with each other and possess high significance effect when $p<0.01$ at 99 percent significance level, $p<0.05$ at 95 percent significance level and $p<0.10$ at 90 percent significance level. The significance association between most of the variables emphasises the importance of examining for possible multicollinearity problem in the regression as examined by Van der Walt et al. (2003). Nevertheless, some variables indicated negative correlation but have a significant impact.

Overall, the finding of this research is quite similar with earlier research, which indicate strong associations of controlled variables, between board size and corporation size with a significance level of $1 \%$ that is aligned with studies of Lehn et. al. (2004) and Julizaerma and Sori (2012). In addition, board size and number of board meetings have negative relationship with asset return but are statistically significant at $1 \%$ significance level. It is close to the research by Julizaerma and Sori (2012), where the board meeting is stated to have a negative but delayed financial performance connection. Furthermore, females' proportion in boards is positively correlated and statistically significant at $5 \%$ significance level with return on assets. However, there are some variables that have negative and insignificant relations with females' representation which indicates that it must be analysed in the regression because of its weak associations that could prevent the multicollinearity issue.

Table- 3. Correlation Analysis

\begin{tabular}{lllllll}
\hline Variables & ROA & POWD & FS & BS & NOBM & FA \\
\hline ROA & 1.000000 & & & & & \\
\hline POWD & 0.125694 & 1.000000 & & & & \\
& $0.0471^{* *}$ & & & & & \\
\hline FS & -0.518404 & 0.025150 & 1.000000 & & & \\
& $0.0000^{* * *}$ & 0.6923 & & & & \\
\hline BS & -0.261893 & 0.113432 & 0.242796 & 1.000000 & & \\
& $0.0000^{* * *}$ & $0.0734^{*}$ & $0.0001^{* * *}$ & & & \\
\hline NOBM & -0.288721 & 0.199533 & 0.389642 & 0.089203 & 1.000000 & \\
& $0.0000^{* * *}$ & $0.0015^{* * *}$ & $0.0000^{* * *}$ & 0.1597 & & \\
\hline FA & 0.101176 & -0.227136 & 0.086259 & -0.242541 & 0.057674 & 1.000000 \\
& 0.1105 & $0.0003^{* * *}$ & 0.1740 & $0.0001^{* * *}$ & 0.3638 & \\
\hline Notes: & l $^{*}$ denot & & & & & \\
\end{tabular}

Notes: $* * *, * *, *$ denote statistically significant at $1 \%, 5 \%$, and $10 \%$ level respectively.

Regression Analysis

OLS regression analysis is tested to determine whether the model is consistent with the data and whether the explanatory variable has an effect on the response variable. According to the regression findings shown in table 4 , some of the variables are relatively positive and have a significant impact on corporate performance that is calculated by ROA. Nonetheless, some variables are related to corporate performance negatively. The independent variable which is the proportion of the female directors examined in this research is positively related to corporation performance and has a significant impact on it when $p<0.05$. This supports the hypothesis that ROA is positively associated with gender diversity of board members and implies that female directors in this study positively influence corporate performance from an accounting perspective, which is similar with the findings gained from Sánchez (2017) in the Spain and Carter et al. (2010) in the US. 
INTERNATIONAL JOURNAL OF ACADEMIC RESEARCH IN BUSINESS AND SOCIAL SCIENCES Vol. 10, No. 8, 2020, E-ISSN: 2222-6990 @ 2020 HRMARS

For the controlled variables, the impact of the board size that is measured by number of board members and the number of board meetings show negative relationships to the business performance. This is consistent with earlier studies by Adam and Ferreira (2004) and Julizaerma and Sori (2012) that fail to find any positive and significant relationship between board size and performance and board meetings and performance. The company age, on the other hand, has positive and significant relation with corporate performance which indicates older corporations in the sample are performing better as compared to younger corporations.

In determining the presence of multicollinearity, test of variance inflation factor (VIF) is carried out as recommended by earlier research (Maran and Indraah, 2009). According to the rule of thumb, if the VIF of variables exceeds 10, that variable is said to be highly collinear. Thus, there is no multicollinearity problem in the analysis because all the predictor variables are ranging from 1.11 to 1.26 .

Table-4. OLS Regression of the Corporate Performance and Gender Diversity

\begin{tabular}{llll}
\hline Model & Coefficient & t-statistic & Significant \\
\hline Percentage of Women Directors & 0.150722 & 4.067991 & 0.0001 \\
\hline Firm Size & -2.133823 & -7.719678 & 0.0000 \\
\hline Board Size & -0.439188 & -2.233982 & 0.0264 \\
\hline Number of Board Meeting & -0.317896 & -2.745843 & 0.0065 \\
\hline Firm Age & 0.080511 & 3.072587 & 0.0024 \\
\hline Constant & 44.11043 & 10.41837 & 0.0000 \\
\hline R-squared & 0.354428 & - & - \\
\hline F-statistic & 26.79191 & - & - \\
\hline
\end{tabular}

\section{Summary of Hypotheses}

Based on the results, it can be concluded that all the hypotheses are backed by past researchers.

Table-5. Summary of the hypothesis

\begin{tabular}{|c|c|c|}
\hline Hypotheses & Results & $\begin{array}{l}\text { Supported/Not } \\
\text { Supported }\end{array}$ \\
\hline $\begin{array}{l}H_{0} \text { : There is a significant relationship between } \\
\text { percentage of women directors and } \\
\text { corporation outcomes }\end{array}$ & Positively significant & Supported \\
\hline $\begin{array}{r}H_{1} \text { : There is a significant relationship between } \\
\text { corporation size and corporation outcomes }\end{array}$ & Negatively significant & Supported \\
\hline $\begin{array}{r}\mathrm{H}_{2} \text { : There is a significant relationship between } \\
\text { board size and corporation outcomes }\end{array}$ & Negatively significant & Supported \\
\hline $\begin{array}{r}H_{3}: \text { There is a significant relationship between } \\
\text { company age and corporation outcomes }\end{array}$ & $\begin{array}{l}\text { Positively } \\
\text { insignificant }\end{array}$ & Supported \\
\hline $\begin{array}{l}H_{4} \text { : There is a significant relationship between } \\
\text { board meetings and corporation outcomes }\end{array}$ & Negatively significant & Supported \\
\hline
\end{tabular}


INTERNATIONAL JOURNAL OF ACADEMIC RESEARCH IN BUSINESS AND SOCIAL SCIENCES Vol. 10, No. 8, 2020, E-ISSN: 2222-6990 @ 2020 HRMARS

\section{Conclusions}

This study has been done with the objective to examine the relationship of gender diversity and firm performance of top 50 listed companies in Malaysia from the year 2014 to 2018. The performance of corporation is measured using ROA. The analytical findings show a positive correlation with explanatory variable which is POWD. Control variables, on the other hand, the findings show a negative correlation between ROA and FS, BS and NOBM. Nonetheless, ROA has a positive correlation with FA. The explanatory variable which is the proportion of the female directors examined in this research is positively related to corporation performance. It reinforces the hypothesis that ROA is strongly related to the diversity of gender in the board members. This may be affected by the strong corporate governance possessed by the sample firms in this research. It can be elaborated by an earlier research carried out by Adams and Ferreira (2009), which indicates that sex diversity of board members is significantly and positively related to asset return, and the corporate governance mechanism is supposed to accountable. This analysis is backed by Johansen's (2008) work that found that the mean of ROA with high proportion of female directors is $8.2 \%$ whereas businesses with lower representation of women simply have poor corporate governance. Thus, it can be stated that the higher proportion of females in boards can have a substantial impact on the performance of the corporation. Regarding the control variables, the effect of the business size, the board size and the number of board meetings show negative relationships to the business performance. Yet all of them show the significant impact on business outcomes where they have a $p$-value of $0.0000,0.0264$, and 0.0065 respectively. This could reflect the fact that smaller boards lead to better financial outcomes as suggested by Yermack (1996). The findings show surprisingly that the size of the corporation is negatively related to ROA and it matches with prior research by Carter et al. (2003). Nonetheless, board meetings have significant impact on firm's outcomes. In addition, the corporation age which is measured by number of years of company operation is positively related to company outcomes. The positive outcome may indicate that older companies perform better than younger companies in the research.

This research is crucial in highlighting the advantages of females' involvement in the corporate boards. Employing ROA as the indicator of accounting performance, the findings indicate that there exists a positively significant relationship between percentage of female directors which represents gender diversity and asset returns. Such findings have been confirmed and validated by earlier researchers who also carried out studies on related topics. This result is aligned with the requirement by Malaysian government that required big companies to achieve 30 percent board diversity by 2016 and has extended until 2020. The Malaysian Code on Corporate Governance also imposed a requirement of having gender diversity in board to all companies. Hence, it is recommended that this approach should be continuously imposed and implemented by business sectors to obtain the benefits of having the mixing of females and males in the boardroom for better corporate performance.

Nonetheless, there are some limitations which cannot be avoided while this research is carried out and can be improve for future study. Firstly, this research employs ordinary least square (OLS) regressions to scrutinizes the impacts of gender diversity in the boards on financial outcomes. OLS regression in its nature only examines the linear connections between response and explanatory variables. In other terms, it believes the correlation is straightforward and sometimes this is wrong. Therefore, future research needs to examine the impacts of corporation outcomes and other company characteristics on the gender diversity of board members through a simultaneous equation 
INTERNATIONAL JOURNAL OF ACADEMIC RESEARCH IN BUSINESS AND SOCIAL SCIENCES Vol. 10, No. 8, 2020, E-ISSN: 2222-6990 @ 2020 HRMARS

framework, as carried out by Campbell and Minguez-Vera (2008). Secondly, this research employs cross-sectional analysis among listed corporations in five financial years of 2014 until 2018 only, which makes the findings cannot be generalized for other financial years. Thus, future research is encouraged to include the use of longitudinal data into consideration to provide more reliable perspectives into the correlation between gender diversity and financial outcomes. This is because the more relevant the results and findings are when there is a longer timeframe for a research. Lastly, the application of ROA as a determinant for financial outcomes has its own shortcomings. The results can be challenged to achieve better outcomes by incorporating different approaches or other financial metrics. Hence, future research needs to consider the use of other approaches or other financial metrics as a measurement to achieve a better finding. To conclude, this study focuses primarily on top 50 firms listed in Main Market of Bursa Malaysia. Hence, there are flaws to be improved to get a more detailed and precise results.

\section{Acknowledgements}

The authors would like to thank for the financial support from Universiti Malaysia Sarawak (UNIMAS). All remaining flaws are the responsibilities of the author.

\section{References}

Adams, R. B., \& Ferreira, D. (2009). Women in the Boardroom and Their Impact on Governance and Performance. Journal of Financial Economics, 291-309.

Campbell, K., \& Mínguez-Vera, A. (2008). Gender Diversity in the Boardroom and Firm Financial Performance. Journal of Business Ethics, 435-451.

Carter, D. A., D'Souza, F., Simkins, B. J., \& Simpson, W. G. (2010). The Gender and Ethnic Diversity of US Boards and Board Committees and Firm Financial Performance. Corporate Governance: An Internation Review, 396-414.

Carter, D. A., Simskins, B. J., \& Simpson, W. G. (2003). Corporate Governance, Board Diversity and Firm Performance. Financial Review, 371-390.

Carter, D. A., Simskins, B. J., \& Simpson, W. G. (2007). The Gender and Ethnic Diversity of US Boards and Board Committees and Firm Financial Performance. Corporate Governance: An International Review, 396-414.

Catalyst. (2008). 2008 Catalyst Census of Women Board Directors of the Fortune 500. New York, NY.

Darmadi, S. (2010). Board Diversity and Firm Performance: The Indonesian Evidence. Corporate Ownership and Control Journal.

Dutta, P., \& Bose, S. (2006). Gender Diversity in the Boardroom and Financial Performance of Commercial Banks: Evidence from Bangladesh. The Cost \& Management, 70-74.

Erhardt, N. L., Werbel, J. D., \& Shrader, C. B. (2003). Board of Director Diversity and Firm Financial Performance. Corporate Governance: An International Review, 102-111.

Gray, D. (2009). Doing Research in the Real World.

Jackling, B., \& Johl, S. (2009). Board Structure and Firm Performance: Evidence from India's Top Companies. Corporate Governance: An International Review, 492-509.

Johansen, E. R. (2008). Gender Diversity and Firm Performance - An Empirical Approach. Thesis Swiss Banking Institute University of Zurich, September. 
INTERNATIONAL JOURNAL OF ACADEMIC RESEARCH IN BUSINESS AND SOCIAL SCIENCES

Vol. 10, No. 8, 2020, E-ISSN: 2222-6990 @ 2020 HRMARS

Julizaerma, K., \& Sori, Z. (2012). Gender Diversity in the Boardroom and Firm Performance of Malaysian Public Listed Companies. Procedia - Social and Behavioral Sciences. 65. 1077-1085. 10.1016/j.sbspro.2012.11.374.

Laffarga, J., Labelle, R., Francoeur, C., \& Gallego, A. C. (2015). Appointing Women to Boards: Is There a Cultural Bias? Journal of Business Ethics, 429.

Lehn, K., Sukesh, P. and Zhao, M. (2004) Determinants of the size and structure of corporate boards: 1935-2000, Working Paper, Katz Graduate School of Business.

Maran, M., \& Indraah, K. (2009). Ethnicity and Gender Diversity in Boards of Directors and Their Relevance to Financial Performance of Malaysian Companies. Journal of Sustainable Development, 139-148.

Robson, C. (2002). Real World Research: A Resource for Social Scientists and Practitioner-Researchers / C. Robson.

Rose, C. (2007). Does Female Board Representation Influence Firm Performance? The Danish Evidence. Corporate Governance: An International Review, 404-413.

Sánchez, M. S., \& Silaghi, F. R. (2017). Women on Corporate Boards and Firm Performance: Evidence from Spain.

Terjesen, S., Singh, V., \& Sealy, R. (2009). Women Directors on Corporate Boards: A Review and Research Agenda. Corporate Governance: An International Review, 320-337.

Van der Walt, N., Ingley, C., Shergill, G. S., \& Towsend, A. (2003). Board Configuration: Are Diverse Boards Better Board? Journal of Corporate Governance, 129-147.

Wang, Y., \& Clift, B. (2009). Is There A "Business Case" for Board Diversity? Pacific Accounting Review, 88-193.

Yermack, D. (1996). Higher Market Valuation of Companies with A Small Board of Directors. Journal of Financial Economics, 185-211. 